\title{
Genetic trends in wood density and radial growth with cambial age in a radiata pine progeny test
}

\author{
Francisco Zamudio $^{\mathrm{a}^{*}}$, Ricardo Baettyg ${ }^{\mathrm{a}}$, Adriana Vergara ${ }^{\mathrm{a}}$, Fernando Guerra ${ }^{\mathrm{a}}$ \\ and Philippe Rozenberg ${ }^{\mathrm{b}}$ \\ ${ }^{a}$ Facultad de Ciencias Forestales, Universidad de Talca, PO Box 747, 2 Norte 685, Talca, Chile \\ ${ }^{\mathrm{b}}$ INRA Orléans, Unité d'Amélioration, Génétique et Physiologie Forestières, BP 20619 Ardon, 45166 Olivet Cedex, France
}

(Received 15 March 2001; accepted 16 July 2002)

\begin{abstract}
The main objective of this study was to describe trends in genetic parameters for wood density and radial growth through cambial age in a radiata pine progeny test established in the south of Chile. Wood samples from 31 half-sib families of radiata pine were obtained and submitted to an X-ray densitometry procedure. The analyzed traits were total ring width (TRW), ring area (RA), and average ring density (ARD). Statistical analyses were conducted to estimate the heritability of individual traits at the ring level and the ring-to-ring genetic correlation between ARD and radial growth. The pattern of change of genetic parameters with cambial age is especially affected between rings 6 to 10 , which can be related with the transition from juvenile wood to adult wood. The genetic control of ring density was strong at cambial ages 2 and 3 and dropped to zero within the transition zone (rings 6 and 8). After ring 10, the genetic control of ARD varied from low to moderate. From cambial ages 3 to 9 , the genetic correlation between ring density and radial growth was positive. From rings 5 to 9 , the phenotypic correlation was also positive but low. At rings 8 and 9, the relationship between radial growth and density changed and strong within-plot competition effects possibly affected the phenotypic correlation between ring density and radial growth. After ring 9 , the genetic correlation was negative but weak. The phenotypic correlation between ring density and radial growth increased its negative magnitude towards cambial age 14, which may have been the result of local micro site influences, such as competition for light and nutrients.
\end{abstract}

wood density / heritability / micro density / ring-ring genetic correlation

Résumé - Contrôle génétique de la densité et de la croissance radiale en fonction de l'âge cambial dans un test de familles de pin radiata. L'objectif de cette analyse est d'évaluer le contrôle génétique de la densité du cerne en fonction de l'âge cambial, et d'estimer les corrélations génétiques entre croissance radiale et densité du bois, en fonction également de l'âge cambial, chez le pin radiata au Chili. Des échantillons de bois provenant de 31 familles de demi-frères de pin radiata installées dans un test de descendances maternelles installé au Chili ont été récoltés et soumis à une procédure d'analyse microdensitométrique aux rayons X. Les caractères analysés sont la largeur de cerne (TRW), la surface du cerne (RA) et la densité moyenne du cerne (ARD). Des analyses statistiques ont permis d'estimer l'héritabilité de ces caractères au niveau du cerne, ainsi que les corrélations génétiques entre caractères de croissance radiale et densité du cerne en fonction de l'âge cambial. La tendance générale de l'évolution des paramètres génétiques change particulièrement au niveau des cernes 6 à 10 depuis la moelle, ce qui reflète peut-être le passage du bois juvénile au bois adulte. Le contrôle génétique de la densité du cerne est élevé aux âges cambiaux 2 et 3 , et tombe à 0 au niveau des cernes 6 à 8. Après le cerne 10, le contrôle génétique de la densité du cerne devient faible à modéré. De l'âge cambial 3 à l'âge cambial 9 , la corrélation génétique entre la densité du cerne et la croissance radiale est positive. Entre les cernes 5 et 9 , la corrélation phénotypique entre les mêmes caractères est également positive, mais faible. Au niveau des cernes 8 et 9 , la relation entre la densité et la croissance radiale change et la corrélation phénotypique entre la densité du cerne et la croissance radiale est alors probablement affectée par de forts effets compétition à l'intérieur des placeaux. Après le cerne 9, la corrélation génétique devient négative mais reste faible. Par contre, la corrélation phénotypique négative entre densité du cerne et croissance radiale devient plus intense jusqu'à culminer à l'âge cambial 14. L'ampleur de cette corrélation phénotypique est peut-être dominée par des effets microsite du type compétition pour la lumière et pour les éléments minéraux.

densité du bois / héritabilité / microdensité / corrélations cerne à cerne

\footnotetext{
* Correspondence and reprints

Tel.: 5671 200379; fax: 5671 200455; e-mail: fzamudio@pehuenche.utalca.cl
} 


\section{INTRODUCTION}

Radiata pine tree breeding programs (RPTBP) started in Chile in the late 70's and nowadays the breeding efforts are concentrated on the second generation of selection. Like the first generation, the RPTBPs continue being mainly oriented towards increasing wood production in the shortest possible time. This approach is still based on the idea that whatever is growing on the field can be transformed in usable goods, and the fact that wood quality related traits were usually difficult and expensive to measure.

The efforts for genetically improving the growth rate for volume of radiata pine in Chile are succeeding and the number of plantations established with selected families (full-sib or half-sib stands) or genotypes (clonal stands) will systematically increase in the future. The objective is to increase the site productivity. It means that the rotation age is expected to decrease in the coming commercial plantings. This outcome will probably be enhanced by the application of intensive silviculture. As a result, we expect that more juvenile wood will be used by the Chilean forest industry in the future. In Europe, for softwood species like Norway spruce, it is generally believed that the increased proportion of juvenile wood in the stem is related with a general decrease of the quality in the final wood products [27]. Thus, we have to predict the impact that this increment in juvenile wood will have on the quality of final products obtained from the future family/clonal stands.

In the long run, the value of any RPTBP can be at risk if the quality of the wood obtained from plantations is not considered within the breeding program. As stated by Ridout et al. [26], the increment in juvenile wood in the future harvest represents a challenge for wood processors and an opportunity for tree breeders. The challenge comes from the future variability in wood quality and the difficulty that processors will have to face in optimizing processing conditions to achieve reliable end product performance [26]. This is particularly serious if the wood from future commercial plantings has highly variable material properties, or shows an undesired degree of heterogeneity. For example, if wood density ranges from very high to very low values, between and within fast growing trees, the future available wood (obtained from fast growing genetic stocks) will not show an adequate relationship between density and biomass production required by the Chilean pulp and paper industry. Also, an excessive variation between the density of juvenile and mature wood could have negative impacts on most solid wood products [37].

Wood density is considered to be the single most important intrinsic wood property for most wood products [3]. But a negative relationship between radial growth and wood density has been widely reported [28]. The strength of the relationship is variable among softwood species; it is very strong for spruces (Picea spp.) and especially Norway spruce (Picea abies) [27, 36], and apparently very weak for some pines (Pinus) species [36]. Different authors have presented some evidence of intraspecific genetic variation in the relationship between growth and wood density [28]. For radiata pine, the literature reported that the genetic correlation between density and diameter growth is either not significant $[20,24]$ or negative [3, 4]. Because this relationship is not clear, we do not know with precision the type of effects produced by the genetic modification of the growth rate on the wood quality of radiata pine in Chile, and this question should be addressed.

In 1998, the University of Talca started a research line aiming to learn more about the influence of a selection based on growth traits at early ages and later ages, as well as on wood quality related traits of radiata pine. This research topic is relevant because the economic advantages of being able to predict the performance of mature trees by observing the performance at earlier ages, and possibly shortening the generation time, is forcing the second generation RPTBPs to seek fast growing trees with a high correlation between early and late cumulative growth. As mentioned in [38], the search for fast growing trees increases the need to study the effects of this selection strategy on the quality of the wood.

Wood density is strongly related with cell dimensions: cell wall thickness and lumen diameter [28]. In softwood species growing under temperate climates, it strongly varies from earlywood to latewood, within rings. The wood formed during the first part of the growing season is low-density wood (often between 200 and $300 \mathrm{~g} \mathrm{dm}^{-3}$ ), while the wood formed during the second part of the growing season shows much higher density (often between $600 \mathrm{~g} \mathrm{dm}^{-3}$ to more than $1000 \mathrm{~g} \mathrm{dm}^{-3}$ ). In a single tree, the within-ring pattern of wood density also changes from ring to ring, from pith to bark, along with cambium aging (from juvenile to mature wood), and with environmental changes [31, 35, 37]. According to the observation scale (the tree, the wood sample of variable size, the ring, the earlywood or the latewood, the cell group, or the cell), each character has its own inheritance pattern [36]. This allows breeders to manipulate efficiently wood density through selection to produce better quality wood, according to the desired scale. Here, we report the first results of a series of studies conducted in one of the largest radiata pine breeding population from Chile. The main objective of this study was to describe trends in genetic parameters of wood density and radial growth with cambial age.

\section{MATERIALS AND METHODS}

\subsection{Progeny test description}

Data came from a progeny test of radiata pine established with 31 open pollinated families in the south of Chile by Forestal Mininco S.A. The test site was located in the Bio-Bio province, within the VIIIth political region (latitude $37^{\circ} 03^{\prime} 05^{\prime}$ ' S, longitude $72^{\circ} 27^{\prime} 20^{\prime \prime} \mathrm{W}$, altitude $122 \mathrm{~m}$ above sea level). The area is flat with a mean annual precipitation of $1100 \mathrm{~mm}$ and a period of 4-5 months of drought. The soil texture is sandy with a good drainage. Trees were planted in 
1981 at a $3 \mathrm{~m} \times 2.5 \mathrm{~m}$ spacing. The experiment was arranged in seven randomized complete blocks and families were established in five-tree row plots. No particular silviculture practice was performed before to the wood sampling.

\subsection{Wood sample collection}

One or two trees per block per family were selected for this study. Trees with physical and mechanical damages were excluded as well as individuals with signs of plagues and diseases. A total of 317 trees were felled down at the end of 1998 (including 23 genetic controls). A wood disk of $20 \mathrm{~cm}$ thickness was obtained at Dbh from each tree and used for assessing physical properties as well as radial growth. The geographical north was also marked on each wood disk, as a reference for further analyses. Along the north radius of each wood disk, a sub sample of $10 \mathrm{~mm}$ wide $\times 1.8 \mathrm{~mm}$ thick was obtained from pith to bark. This direction was chosen to minimize the presence of compression wood, since the prevailing winds were from the southwest. Wood samples were dried to equilibrium moisture of $12 \%$.

\subsection{Trait measurements}

Resins in the wood samples were extracted with alcohol. Wood samples were submitted to an indirect-reading X-ray densitometry procedure. The X-ray film of wood samples was digitalized by using a scanner with a color resolution of 8 bits (256 tones of gray) and a spatial resolution of 300 pixels/inch. Each pixel covered a length of $0.085 \mathrm{~mm}$. The digitalized images were processed by using the WinDENDRO software [10]. The initial raw data consisted of a wood density profile at the pixel level. Ring limits were also determined with this software and a careful visual observation of the actual wood samples. The last step in the data generation process used a computer routine written in $\mathrm{C}$ language to measure the following two traits: average ring density (ARD) and total ring width (TRW). The TRW trait allowed estimating the stem area occupied by the ring, or ring area (RA), by using the following expression:

$$
\mathrm{RA}_{\mathrm{t}}=\mathrm{CSA}_{\mathrm{t}}-\mathrm{CSA}_{\mathrm{t}-1}
$$

where $\mathrm{CSA}_{t}$ and $\mathrm{CSA}_{t-1}$ are the cumulative stem area measured from pith to the external border of rings numbers $t$ and $t-1$, respectively.

If two trees with the same diameter increment had different initial diameter, they also had different basal area increments. Thus, the diameter and basal area increments could be regarded as different growth expressions [33]. As a result, we considered that TRW and RA were two different ways to measure radial growth in trees, and both traits were compared to ARD. The measurement units used for TRW, ARD, and RA were millimeters ( $\mathrm{mm}$ ), kilograms per cubic meter $\left(\mathrm{kg} \mathrm{m}^{-3}\right)$, and squared centimeters $\left(\mathrm{cm}^{2}\right)$, respectively.

In this paper, we attempted to measure the relationship between ring density and radial growth by using the cambial age as reference for arranging the data obtained from the micro density profiles. In a progeny test, all trees are the same age but do not necessarily grow at the same rate. Thus, they might not reach a given height at the same age and the number of rings in a sample collected at breast height (or at any height common to all sampled trees) could vary from one tree to the next [26]. In our study, all trees were planted the same year. We already know that at the planting time, each seedling was one year under nursery conditions and around $30 \mathrm{~cm}$ tall. At the end of the second growing season, the surviving young trees were in average close to $2 \mathrm{~m}$ tall and we are assuming they had three rings at the ground level. By extension, the first ring detected by the micro density profiles was assumed to be the ring generated at age three and was discarded from the analysis because it did not fully record the radial growth from the whole growing season. Thus, the first ring of reference was number 2 , which was assumed to correspond to age 4 . Hence, only measurements from rings 2 to 14 were included in the study. This ensured the same sampling precision at all rings.

\subsection{Statistical analyses}

The mixed linear model associated to the data for a given trait measured at a particular ring is

$$
\mathrm{Y}_{i j k}=\mu+\mathrm{B}_{i}+\mathrm{F}_{j}+\mathrm{BxF}_{i j}+\mathrm{e}_{i j k}
$$

where $\mathrm{Y}_{i j k}$ is the phenotypic individual observation; $\mu$ is the overall mean; $\mathrm{B}_{i}$ is the fixed block effect; $\mathrm{F}_{j}$ is the random family effect with mean zero and variance $\sigma_{\mathrm{F}}^{2} ; \mathrm{BxF}_{i j}$ is the random interaction or plot effect with mean zero and variance $\sigma_{\mathrm{BF}}^{2}$; and $\mathrm{e}_{i j k}$ is the random residual effect with mean zero and variance $\sigma_{\mathrm{e}}^{2}$. It is also assumed that $\mathrm{Y}_{i j k}$ has mean $\mu+\mathrm{B}_{i}$ and the phenotypic variance was estimated as $\sigma_{\mathrm{P}}^{2}=\sigma_{\mathrm{F}}^{2}+\sigma_{\mathrm{BF}}^{2}+\sigma_{\mathrm{e}}^{2}$. Families were considered to be maternal half-sibs, therefore the following relationships were assumed to estimate genetic parameters:

$$
\mathrm{V}_{\mathrm{Ax}}=4 \sigma_{\mathrm{Fx}}^{2}
$$

and

$$
\operatorname{Cov}\left(A_{x}, A_{y}\right)=4 \operatorname{Cov}_{\text {Fxy }}
$$

where $\mathrm{V}_{\mathrm{Ax}}$ and $\sigma_{\mathrm{Fx}}^{2}$ are the additive genetic variance and family variance component for trait $\mathrm{X}$, respectively; and $\operatorname{Cov}\left(\mathrm{A}_{\mathrm{x}}, \mathrm{A}_{\mathrm{y}}\right)$ and $\operatorname{Cov}_{\mathrm{Fxy}}$ are the additive genetic covariance and family covariance component between traits $\mathrm{X}$ and $\mathrm{Y}$, respectively.

The final data set used in this study was unbalanced due to the sampling scheme ( 1 to 2 healthy trees per family and block). The normality of experimental data was checked using the SAS INSIGHT procedure [29]. Analyses of variance were conducted for all traits and cambial age, and type III sum of squares were calculated using the SAS GLM procedure [29]. The Satterthwaite's approximated test was used to measure the level of significance of family related effects [25]. Variance components, for each trait and cambial age, and covariance components, for each age and between traits, were estimated using the restricted maximum likelihood principle and the SAS MIXED procedure [16].

\subsection{Genetic parameter estimates}

The narrow-sense individual tree heritability $\left(\mathrm{h}^{2}\right)$ was calculated for each trait measured at the $\mathrm{t}$-th cambial age (ring number) as

$$
h^{2}=\frac{4 \sigma_{\mathrm{F}}^{2}}{\sigma_{\mathrm{P}}^{2}}
$$

where $\sigma_{\mathrm{F}}^{2}$ and $\sigma_{\mathrm{P}}^{2}$ are the family variance components and phenotypic variance, respectively. Approximate standard error of heritability estimates were calculated by using the asymptotic large-sample dispersion matrix associated to the REML method [30], and the Taylor series expansion analysis [17].

Genetic correlation $\left(r_{\text {gxy }}\right)$ between two different traits ( $X$ and $Y$ ), measured at the $\mathrm{t}$-th particular cambial age, was further estimated as

$$
r_{\mathrm{gxy}}=\frac{\operatorname{Cov}_{\mathrm{Fxy}}}{\left(\sigma_{\mathrm{Fx}}^{2} \sigma_{\mathrm{Fy}}^{2}\right)^{1 / 2}}
$$

where $\operatorname{Cov}_{\mathrm{Fxy}}$ was defined above and $\sigma_{\mathrm{Fx}}^{2}$ and $\sigma_{\mathrm{Fy}}^{2}$ are the family variance components for traits $\mathrm{X}$ and $\mathrm{Y}$, respectively. Approximate standard error (sampling variance) of the genetic correlation estimates were also obtained by using the asymptotic large-sample 
A

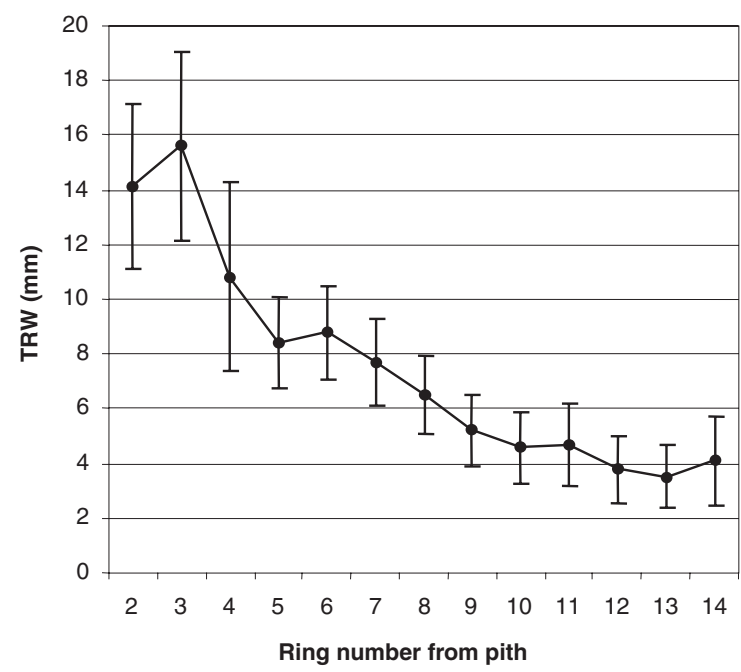

B

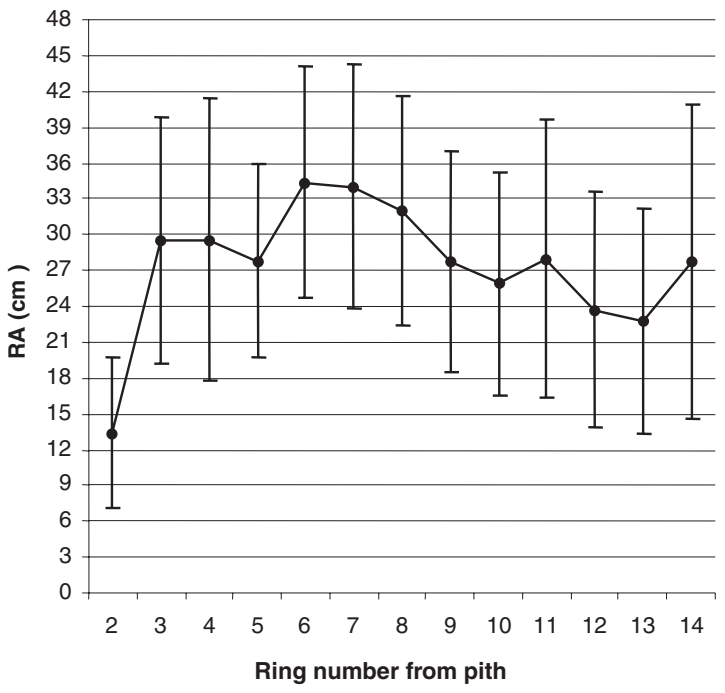

C

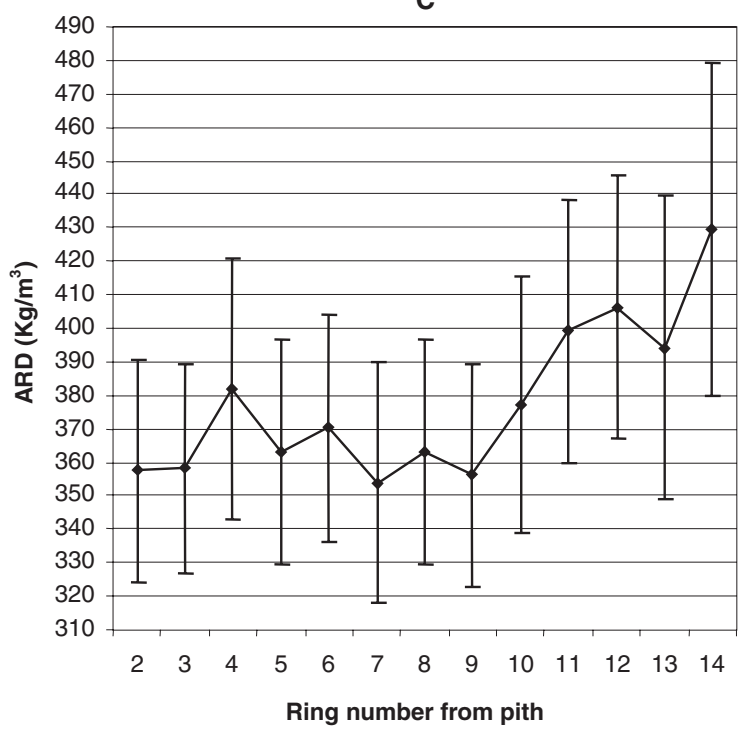

dispersion matrix associated to the REML method [30], and the formulae given by Becker [2].

The phenotypic covariance between traits $\mathrm{X}$ and $\mathrm{Y}$ was measured as $\operatorname{Cov}_{\mathrm{Pxy}}=\mathrm{Cov}_{\mathrm{Fxy}}+\operatorname{Cov}_{\mathrm{BFxy}}+\operatorname{Cov}_{\mathrm{exy}}$, which is the sum of the family, interaction, and residual covariance components, respectively. The phenotypic correlation $\left(\mathrm{r}_{\mathrm{pxy}}\right)$ between traits $\mathrm{X}$ and $\mathrm{Y}$, also measured at the $\mathrm{t}$-th cambial age, was estimated as

$$
r_{\text {Pxy }}=\frac{\operatorname{Cov}_{\text {Pxy }}}{\left(\sigma_{\mathrm{Px}}^{2} \sigma_{\mathrm{Py}}^{2}\right)^{1 / 2}}
$$

where $\sigma_{\text {Px }}^{2}$ and $\sigma_{\text {Py }}^{2}$ are the phenotypic variances for traits $\mathrm{X}$ and $\mathrm{Y}$, respectively.

\section{RESULTS AND DISCUSION}

\subsection{Means}

Figures $1 a, 1 b$ and $1 c$ show changes in average value through cambial age for TRW, RA, and ARD, respectively (including all data and no family discrimination). TWR decreased as ring number increased. The maximum and minimum values were $15.6 \mathrm{~mm}$, at ring 3 , and $3.5 \mathrm{~mm}$, at ring 13 , respectively. RA increased from rings $2\left(13.4 \mathrm{~cm}^{2}\right)$ to 6 $\left(34.4 \mathrm{~cm}^{2}\right)$, but decreased from rings $7\left(34.0 \mathrm{~cm}^{2}\right)$ to 13 $\left(22.7 \mathrm{~cm}^{2}\right)$. Though RA is a function of TRW, both traits expressed a different trend because RA can still increase from pith outward despite TRW decreases. This is due to the effect of adding new rings of biomass in the periphery of the stem [35]. The total mean value of ARD also recorded a changing pattern between rings $2\left(357.5 \mathrm{Kg} \mathrm{m}^{-3}\right)$ and $9\left(356 \mathrm{Kg} \mathrm{m}^{-3}\right)$, but systematically increased after ring $10\left(377 \mathrm{Kg} \mathrm{m}^{-3}\right)$ and reached the maximum average value at ring 14 $\left(429.6 \mathrm{Kg} \mathrm{m}^{-3}\right)$. The same pattern of changes in mean TRD and ARD with cambial age were recently reported by Cown and Ball [6], who study ten families of radiata pine established in seven sites in New Zealand. This pattern is typical of a transition from juvenile to mature wood.

\subsection{Heritability}

Genetic control of TRW (figure $2 a$ ) diminished from rings $2(0.31)$ to $4(0.02)$, and increased from rings $5(0.09)$ to 14 $(0.46)$. The highest heritability estimate was recorded at ring 13 (0.48). Heritability for RA (figure $2 b$ ) also decreased from rings $2(0.25)$ to $8(0.04)$ and increased from ring $9(0.19)$ to 14 (0.43), where it reached the highest value. In contrast, heritability for ARD showed a different time trend (figure $2 c$ ). There was a large drop in heritability from a maximum at ring $2(0.6)$ to a zero value at ring 6 . From rings 7 to 14 , the heritability increased and decreased in an oscillatory

Figure 1. Average values and standard errors for (A) tree ring width (TRW); (B) ring area (RA) and (C) average ring density (ARD) by cambial age. 


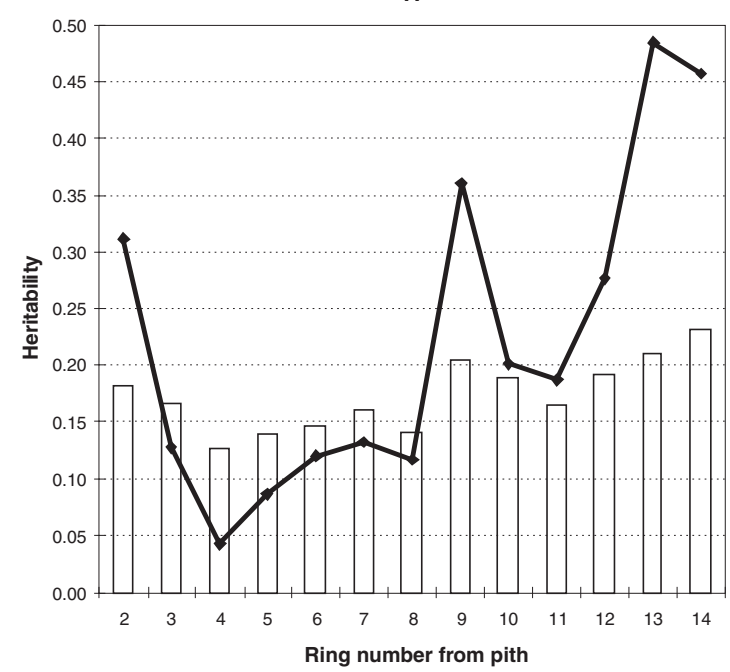

$\square$ Standard Error $\boldsymbol{\sim}$ - Heritability for TRW

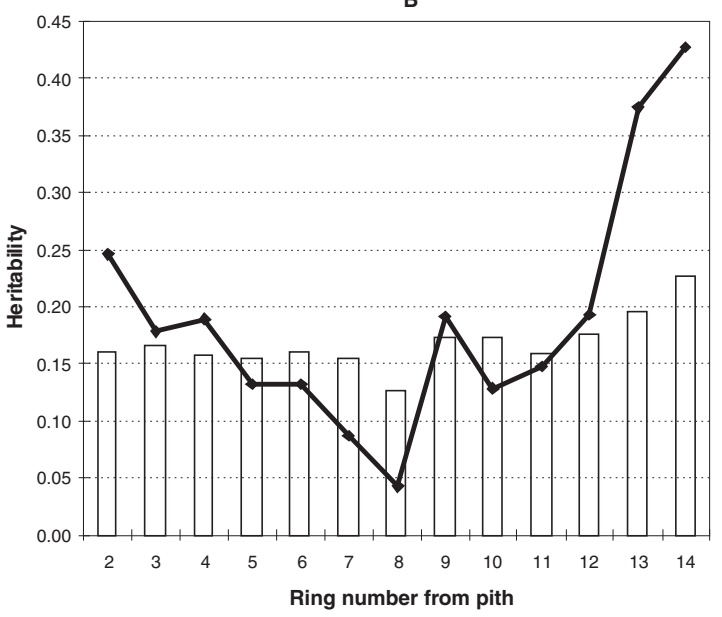

$\square$ Standard Error $\multimap$ Heritability for RA

C

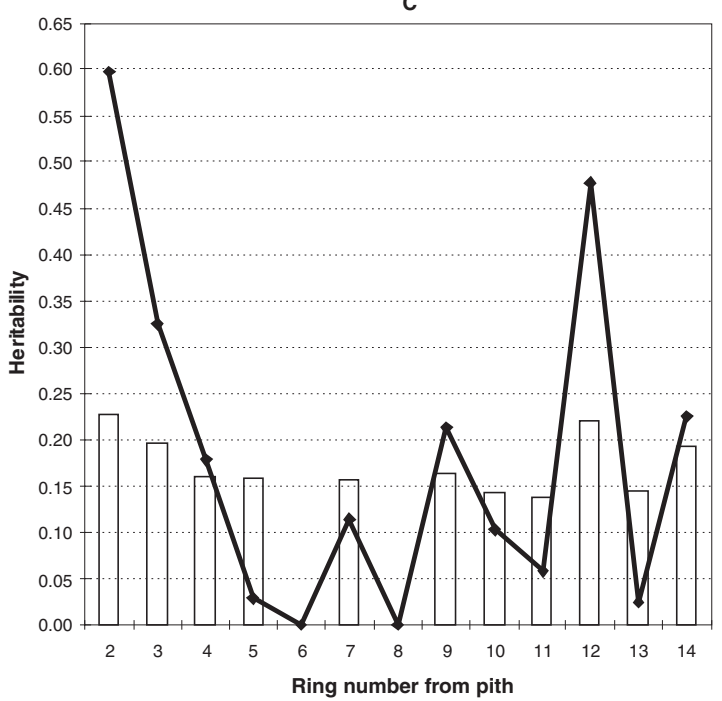

Table I. Level of significance related to the family effect and cambial age.

\begin{tabular}{|c|c|c|c|c|c|c|}
\hline \multirow{2}{*}{$\begin{array}{l}\text { Ring } \\
\text { Number }\end{array}$} & \multicolumn{2}{|c|}{ ARD } & \multicolumn{2}{|c|}{ TRW } & \multicolumn{2}{|c|}{ RA } \\
\hline & Fc & $P$-value & $\mathrm{Fc}$ & $P$-value & Fc & $P$-value \\
\hline $\begin{array}{c}2 \\
3 \\
4 \\
5 \\
6 \\
7 \\
8 \\
9 \\
10 \\
11 \\
12 \\
13 \\
14\end{array}$ & $\begin{array}{l}2.75 \\
1.76 \\
1.52 \\
0.98 \\
1.06 \\
1.12 \\
1.01 \\
1.54 \\
1.47 \\
1.38 \\
2.21 \\
1.09 \\
1.54\end{array}$ & $\begin{array}{l}0.001 \\
0.019 \\
0.062 \\
0.505 \\
0.402 \\
0.327 \\
0.464 \\
0.056 \\
0.077 \\
0.120 \\
0.002 \\
0.361 \\
0.057\end{array}$ & $\begin{array}{l}1.87 \\
1.54 \\
1.02 \\
1.07 \\
1.34 \\
1.27 \\
1.32 \\
1.77 \\
1.35 \\
1.38 \\
1.46 \\
2.27 \\
2.27\end{array}$ & $\begin{array}{l}0.010 \\
0.056 \\
0.453 \\
0.389 \\
0.140 \\
0.189 \\
0.155 \\
0.018 \\
0.135 \\
0.117 \\
0.083 \\
0.001 \\
0.001\end{array}$ & $\begin{array}{l}1.82 \\
1.65 \\
1.50 \\
1.31 \\
1.52 \\
1.31 \\
1.21 \\
1.40 \\
1.22 \\
1.33 \\
1.32 \\
1.88 \\
2.17\end{array}$ & $\begin{array}{l}0.013 \\
0.033 \\
0.070 \\
0.158 \\
0.063 \\
0.159 \\
0.240 \\
0.107 \\
0.228 \\
0.147 \\
0.155 \\
0.010 \\
0.002\end{array}$ \\
\hline
\end{tabular}

Note: Results from the analysis of variance. Fc corresponds to the adequate ratio between type III mean squares and the Satterwhite's approximation; $P$-value is there lated probability; ARD: average ring density $\left(\mathrm{kg} \mathrm{m}^{-3}\right)$; TRW: total ring width $(\mathrm{mm})$; RA: ring area $\left(\mathrm{cm}^{2}\right)$.

pattern. For all traits, the highest heritability estimates were recorded when the family variance component was highly significant (table I). For example, family variances for TRW and RA were highly different at rings 13 and $14(P$-value $<0.01)$ and no statistical differences $(P$-value $>0.05)$ were observed between rings 3 and 12, except at ring 3 for RA $(P$-value $=0.033)$ and ring 9 for TRW $(P$-value $=0.018)$. For ARD, the largest family variances were recorded at rings 2 $(P$-value $=0.001)$ and $12(P$-value $=0.002)$. In contrast, rings 5,6 , and 8 simultaneously registered the lowest family variance $(P$-value $>0.4)$ and heritability estimates were negligible $\left(\mathrm{h}^{2}<0.05\right)$.

Heritabilities were estimated from a single site and can be biased upward because they also estimated the sum of additive plus additive $\times$ environment variance relative to the total phenotypic variance [13]. In fact, the estimate of variance among families included both the family variance and the family $\times$ environment interaction variance, and could be biased compared to a multisite estimate of $\sigma_{F}^{2}[5,34]$. Heritability values obtained at a particular site are valuable for understanding the genetic architecture of the breeding population submitted to local environmental conditions [19]. Our results included a sample of 31 families from a larger breeding population and the recorded genetic variation should be considered as a response to specific environmental conditions, mainly characterized by a sandy soil, a precipitation rate of $1100 \mathrm{~mm} \mathrm{year}^{-1}$, and a drought period close to 5 months. For designing breeding strategies, or predicting

Figure 2. Age trends in individual tree heritability for (A) tree ring width (TRW); (B) ring area (RA) and (C) average ring density (ARD) at different ring numbers counted from the pith. 
breeding values, we should account for differences from site to site in parameters like heritability [13]. In the case of within-site selection: genetic parameters have to be estimated within each site if there is a significant $\mathrm{G} \times \mathrm{E}$ interaction. While in multisite selection, genetic parameters have to be estimated across all sites, including $\mathrm{G} \times \mathrm{E}$ components. If there is no significant $\mathrm{G} \times \mathrm{E}$ interaction, within site genetic parameters may be averaged over all sites (provided the homogeneity of within site variance - covariance matrices).

Zobel and Jett [36] mentioned few publications cited that show a change in heritability with ring number from the center. In radiata pine, Nicholls [21] found a systematic change in heritability with cambial age for wood density. He reported that the heritability of basic density in radiata pine decreased from the pith outward until a minimum was reached about the ninth growth ring from the pith followed by an increase in genetic control with further increase in age. In a further paper [22], the same author states that the genetic control of this trait appears to be a maximum at early life of the tree and therefore maximum gains from selection can be obtained in the first-formed wood. Results obtained here seem to be in agreement with Nicholls' early statements: the maximum value was reached at ring 2 and the minimum at rings 6 and 8 . In contrast, Zobel and Jett [36] stressed that for other species, such as loblolly pine, heritability has a clear tendency to increase with cambial age. In a study conducted in slash pine (Pinus elliottii), Hodge and Purnell [12] also found that the heritability of density for rings near the pith was slightly higher than outward. In their study of families of radiata pine established in several sites in New Zealand, Cown and Ball [6] also measured average ring density and determined that heritabilities of wood density located at the juvenile (rings 1 to 10 ) and mature (rings $11+$ ) wood sections were 0.62 and 0.68 , respectively.

\subsection{Family covariances and genetic correlations}

Estimated genetic correlations $\left(\mathrm{r}_{\mathrm{gxy}}\right)$ and associated standard errors (SE), are presented in table II. Genetic correlations between ring density and radial growth could not be estimated at rings 6 and 8 because the family variance component for ARD was zero. The standard errors were generally higher than the correlation estimates, with several standard errors greater than one. Therefore, the estimated genetic correlations reported here should be used with caution. Despite the large standard errors, we can still detect a pattern in the genetic relationship between ring density and radial growth. This can be done by observing the simultaneous changes with cambial age in the different covariance components that make up the phenotypic covariance. For example, trends in family covariation with cambial age are shown in figures $3 a$, for ARD versus TRW, and $3 b$, for ARD versus RA. At ring 2 and between rings 10 and 14, family covariances were negative in both cases; except ring 11 that recorded a light positive covariation between ARD and TRW. This means that genetic
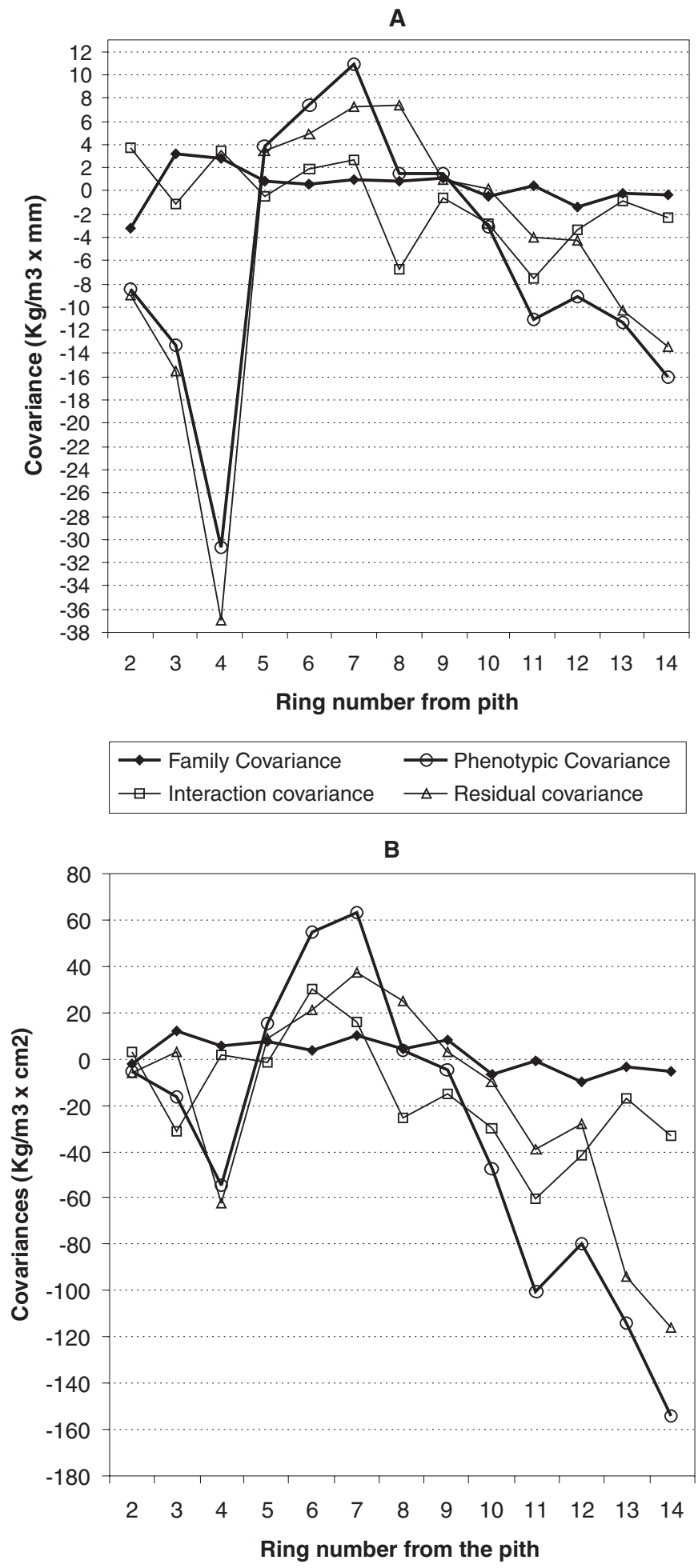

Figure 3. Age trends in family, interaction, residual, and phenotypic covariance components for (A) ARD versus TRW and (B) ARD versus RA at different ring number counted from the pith. 
Table II. Genetic and phenotypic correlations between ring density (ARD) and radial growth (TRW and RA) at different ring number counted from the pith. Standard errors are given in parenthesis.

\begin{tabular}{|c|c|c|c|c|c|c|}
\hline \multirow{2}{*}{$\begin{array}{l}\text { Ring } \\
\text { Number }\end{array}$} & \multicolumn{4}{|c|}{ Genetic Correlations } & \multicolumn{2}{|c|}{ Phenotypic Correlations } \\
\hline & ARD v & TRW & ARD & S RA & ARD v/s TRW & ARD v/s RA \\
\hline $\begin{array}{c}2 \\
3 \\
4 \\
5 \\
6 \\
7 \\
8 \\
9 \\
10 \\
11 \\
12 \\
13 \\
14\end{array}$ & $\begin{array}{r}-0.30 \\
0.58 \\
0.97 \\
1.15 \\
\text { indet. } \\
0.57 \\
\text { indet. } \\
0.36 \\
-0.23 \\
0.28 \\
-0.33 \\
-0.10 \\
-0.04\end{array}$ & $\begin{array}{l}{[0.35]} \\
{[0.72]} \\
{[1.92]} \\
{[3.65]} \\
\text { indet. } \\
{[0.81]} \\
\text { indet. } \\
{[0.48]} \\
{[0.80]} \\
{[1.25]} \\
{[0.39]} \\
{[1.12]} \\
{[0.46]}\end{array}$ & $\begin{array}{r}-0.10 \\
0.62 \\
0.27 \\
1.71 \\
\text { indet. } \\
1.08 \\
\text { indet. } \\
0.52 \\
-0.64 \\
-0.09 \\
-0.35 \\
-0.34 \\
-0.10\end{array}$ & $\begin{array}{l}{[0.39]} \\
{[0.61]} \\
{[0.65]} \\
{[4.70]} \\
\text { indet. } \\
{[1.09]} \\
\text { indet. } \\
{[0.65]} \\
{[0.89]} \\
{[1.16]} \\
{[0.43]} \\
{[1.27]} \\
{[0.48]}\end{array}$ & $\begin{array}{r}-0.08 \\
-0.12 \\
-0.23 \\
0.06 \\
0.14 \\
0.19 \\
0.03 \\
0.03 \\
-0.06 \\
-0.19 \\
-0.19 \\
-0.23 \\
-0.19\end{array}$ & $\begin{array}{r}-0.03 \\
-0.05 \\
-0.12 \\
0.05 \\
0.17 \\
0.17 \\
0.01 \\
-0.02 \\
-0.13 \\
-0.22 \\
-0.21 \\
-0.27 \\
-0.22\end{array}$ \\
\hline
\end{tabular}

Note: ARD: average ring density; TRW: total ring width; RA: ring area; indet.: indeterminate.

correlations between ARD and radial growth were also positive at rings 6 and 8 .

Individual tree phenotypic correlations $\left(\mathrm{r}_{\mathrm{Pxy}}\right)$ between ring density and radial growth showed a trend with cambial age that can be separated in three periods (table II). First, between cambial ages 2 and 4, correlations were negative and increased their absolute value towards ring 4 . Second, between cambial ages 5 and 8 , for ARD versus TRW, or 9, for ARD versus RA, correlations were positive and reached a maximum at ring 7 , where the value was 0.19 , for ARD versus TRW, and 0.17, for ARD versus RA. Third, between rings 10 and 14 , correlations were again negative. The largest negative correlations were recorded at ring 13 , with values -0.23 , between ARD and TRW, and -0.27, between ARD and RA. From figures $3 a$ and $3 b$, we observe that the within-plot (residual) covariance follows the same pattern than the phenotypic covariation, and at some cambial ages both covariances closely approach their magnitude. The contribution of the family covariance expressed as a proportion of the total phenotypic covariation is given in figure 4. Because the total phenotypic covariance showed a higher fluctuation with cambial age than family covariance, an increment in the proportion suggests that the phenotypic covariance approached the family covariance due to non-family effects. This was the case at rings 8 and 9, where the proportion for ARD versus TRW was higher than one because the family-by-block and residual covariances recorded very similar values but opposite sign and they cancelled each other, which made the phenotypic covariance to be smaller than the family covariance (figure $3 a$ ). A proportion higher than 50\% could be observed also at rings 8 and 9 for ARD versus RA ( $f i g$ ure $3 b$ ), and rings 3 and 5 for ARD versus TRW. After ring 9, the proportion of family covariance was not higher than $20 \%$ of the phenotypic covariance.

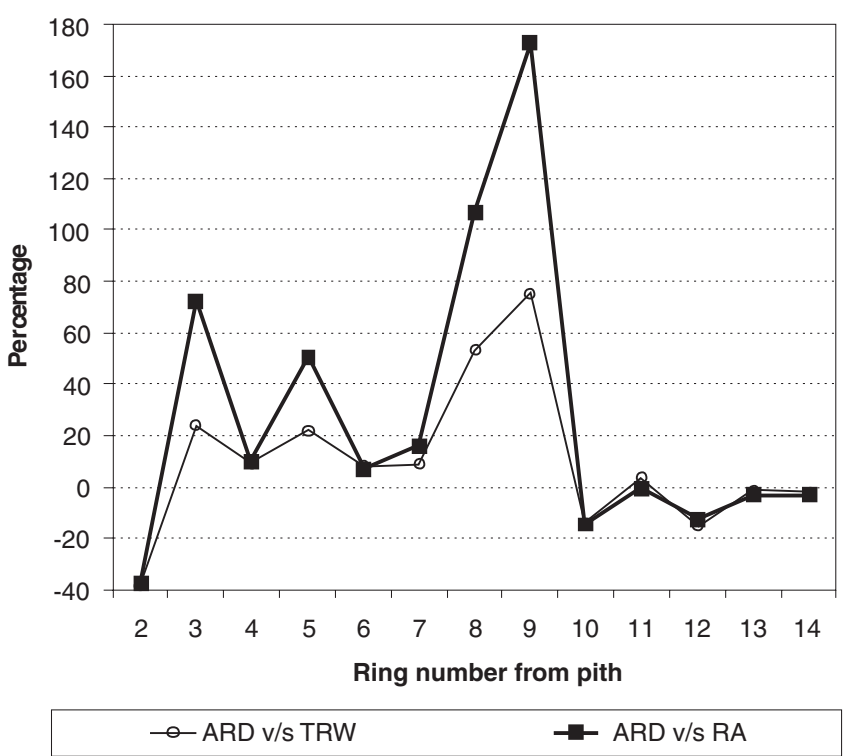

Figure 4. Age trends in percentage of contribution of the family covariance component respect to the phenotypic covariance for ARD versus TRW and ARD versus RA at different ring numbers counted from the pith.

\subsection{Effect of the transition zone from juvenile to mature wood}

The process of wood formation in the progenies included in the study started with a highly significant family variation in density and radial growth at cambial age 2. After the accumulation of four rings of growth, the family variance for density quickly dropped to zero at rings 6 and 8 . The family variation again increased during the last three cambial ages. These results suggest that families expressed one of two different trends of ring variation for ARD. Some families showed a high average ring density at very early cambial ages, which decreased as cambial age approached age 6 . Other families recorded a low ARD close to the pith, which increased towards ring 6 . As a result, there were minimum differences in average ARDs from both types of families and between rings 6 and 8 . The negative genetic correlation between ARD and radial growth at cambial age 2 shows ( $t a-$ ble II) that families with the highest ring density did not necessarily recorded the largest TRW and RA.

Nicholls [23] also discuss the presence of different patterns of changes in ring density from pith outwards in radiata pine and shows that basic density in radiata pine generally increased from the pith outwards. He also reported that some radiata pine trees expressed a variant of this pattern. They exhibited an initial decrease in the first few growth rings before the increase outwards, or small increases in basic density immediately adjacent to the pith. Vargas-Hernandez et al. [32] also mention that some coniferous species show a tendency to increase ring density outward from the pith, between 
10 to 20 years, before leveling off [7]. In contrast, there are some reports that ring density in young coastal Douglas-fir decreases for the first 3 to 5 annual rings from the pith, followed by a gradual increase as the distance from pith increases $[14,18]$.

For radiata pine, Zobel and Jett [36] mention that juvenile wood is the wood located within the first 10 rings from pith. If we assume that ring 2 correspond to biological age 4 in this example, rings 6 to 10 cover the wood formed between ages 8 and 12 , which could correspond to the transition zone between juvenile to mature wood. This area seems to have had a strong effect in the results reported here. Between cambial ages 3 to 9, the family covariance component between ARD and radial growth was positive (figures $3 a$ and $3 b$ ), but the genetic correlation could not be estimated with high precision (table II). In this region, families with a higher mean radial growth also formed wood with a higher mean density.

At rings 8 and 9, the magnitude of the phenotypic covariance closely approached the value of the family covariance component. In this area, the relationship between radial growth and density changed. In the region where the progeny test was established, the canopy started closing around ages 6 to 8 , which corresponds to rings 4 to 6 . This suggests that strong within-plot competition effects possibly affected the phenotypic correlation between ring density and radial growth. Notice that during cambial ages 8 and 9 , covariances of family $\times$ block effects were negative (figures $3 a$ and $3 b)$.

After ring 9, family covariation was negative but the genetic correlation was weak. On the contrary, the phenotypic correlation between ring density and radial growth increased its negative magnitude towards cambial age 14 . In this new region, families with a higher mean radial growth tended to produce wood with a lower mean density. However, family covariation expressed a more stable pattern of changes with cambial age than non-family covariance components. In fact, the magnitude of phenotypic correlation may have been dominated by local micro site influences, such as competition for light and nutrients.

Cown et al. [8] summarized several studies regarding the effect of growth rate on the density of radiata pine saying that there is no clear correlation between growth rate and density, though Banister and Vine [1] found a weak negative phenotypic correlation between both type of traits. Cown et al. [8] also added that tree age, not tree growth rate was the key-determining factor for wood density in all site conditions studied by them. Nicholls et al. [24] also reported a small, non-significant genetic correlation between ring width and average density, and the presence of a small negative correlation that tended to disappear in older growth rings, which agrees to the results presented here. In contrast, Burdon and Young [4] recorded a strong negative correlation between wood density and growth rate in rings 6 to 10 , weaker in rings 10 to 20 and absent in rings 0 to 5 . Our results are in disagreement with this study. Reports of a negative relationship between growth rate and wood density in several genera, such as spruce (Picea spp.) and fir (Abies spp.), have been given by Zobel and Jett [36]. Ling et al. [15] also reports a strong negative correlation between wood density and diameter growth in Douglas-fir.

Wood density affects the strength of solid wood products [11], the evaluation of pulp yield [9], and in combination with tracheid length the strength properties of kraft-pulp [38]. Despite of the clear influence of wood density on the quality of different end products, the breeding efforts in fast growing tree species are still concentrated on growth. As a result, most of the more advanced tree breeding programs have already documented a large realized genetic gain in stem diameter growth, which have enabled reductions in rotation age [37]. There are many publications that describe the relationship between growth rate and wood properties (a good summary can be found in [35]. Overall, many papers report that there is little relationship between both types of traits; some show a negative relationship and few show a positive relationship [36]. Thus, it is generally assumed that a fast grower tree may have either a higher or lower wood density than a slow grower. Because this lack of a clear relationship, we do not know with precision what sort of effect the genetic modification of the growth rate is producing on the genetic of wood production of radiata pine in Chile, and our results are trying to give some insights about this question.

\section{CONCLUSIONS}

The transition zone between juvenile to mature wood (rings 6 to 10) had an influence in the pattern of changes of genetic parameters with cambial age. The genetic control of ring density was strong at early cambial ages (rings 2 and 3 ) and dropped to zero within the transition zone (rings 6 and 8). After ring 10, the genetic control of ARD varied from low to moderate. From cambial ages 3 to 9, the genetic correlation between ring density and radial growth (TRW and RA) was positive but estimates should be used with caution because of the low precision. In this region, families with a higher mean radial growth have a tendency to form wood with a higher mean density. From rings 5 to 9 , the phenotypic correlation was also positive but low. Between rings 8 and 9, the relationship between radial growth and density changed and strong within-plot competition effects possibly affected the phenotypic correlation between ring density and radial growth. After ring 9, the genetic correlation was negative but weak. On the contrary, the phenotypic correlation between ring density and radial growth increased its negative magnitude towards cambial age 14. In this new region, families with a higher mean radial growth showed a tendency to produce wood with a lower mean density. The magnitude of phenotypic correlation may have been dominated by local 
micro site influences, such as competition for light and nutrients.

Acknowledgments: This research was funded by the Chilean National Science and Technology Commission (CONICYT), grant FONDECYT No 1980049. Support came also from the ECOSCONICYT grant No C97B04. The authors are also grateful to Mr. Carlos Gantz, Mr. Victor Sierra, and Mr. Rosamel Saez, from Forestal Mininco S.A. for their technical support in the field, for providing the database, and for allowing publishing of the results of this study. The field experiment complies with the current Chilean laws regarding safety and environmental issues.

\section{REFERENCES}

[1] Banister M.H., Vine M.H., An early progeny trial in Pinus radiata 4. Wood density, N. Z. J. For. Sci. 11 (1981) 221-243.

[2] Becker W.A., Manual of procedures in quantitative genetics, 2nd ed., Washington State University Press, Pullman, Was, 1967, 130 p.

[3] Burdon R.D., Low C.B., Genetic survey of Pinus radiata. 6: Wood properties: variation, heritabilities, and interrelationships with other traits, N.Z. J. For. Sci. 22 (1992) 228-245.

[4] Burdon R.D., Young G.D., Preliminary genetic parameter estimates for wood properties from top-ranked Pinus radiata progenies and comparisons with controls, Proc. 11th Meet. Rep. Res. Work. Grp. No 1 (Forest Genetics) Australian For. Council Coonawarra, South Australia, 1991, pp. 137-140.

[5] Comstock R.E., Moll R.H., Genotype-environment interactions, in: Hanson R.E., Robinson H.F. (Eds.), Statistical genetics and plant breeding, NAS-NRC pub. 982, Washington DC, 1963, pp. 169-194.

[6] Cown D.J., Ball R.D., Wood densitometry of 10 Pinus radiata families at seven contrasting sites: influence of tree age, site, and genotype, N. Z. J. For. Sci. 31 (2001) 88-100.

[7] Cown D.J., Parker M.L., Densitometric analysis of wood from five Douglas-fir provenances, Silvae Genet. 28 (1979) 48-53.

[8] Cown D.J., Parker M.L., Kimberly M.O., Spiral grain patterns in plantation- grown Pinus radiata, N. Z. J. For. Sci. 21 (1991) 206-216.

[9] Dutilleul P., Herman M., Avella-Shaw T., Growth rate effects on correlations among ring width, wood density, and mean tracheid length in Norway spruce (Picea abies), Can. J. For. Res. 28 (1998) 56-68.

[10] Guay R., Gagnon R., Morin H., A new automatic and interactive tree ring measurement system based on a line scan camera, The Forestry Chronicle 68 (1992) 138-141.

[11] Hannrup B., Wilhelmsson L., Danell O., Time trends for genetic parameters of wood density and growth traits in Pinus sylvestris L., Silvae Genet. 47 (1998) 214-219.

[12] Hodge G.R., Purnell R.C., Genetic parameter estimates for wood density, transition age, and radial growth in slash pine, Can. J. For. Res. 23 (1993) 1881-1891

[13] Hodge G.R., White T.L., Genetic parameter estimates for growth traits at different ages in slash pine and some implications for breeding, Silvae Genet. 41 (1992) 252-262.

[14] Jozsa L.A., Brix H., The effect of fertilization and thinning on wood quality of a 24-year-old Douglas-fir stand, Can. J. For. Res. 19 (1989) $1137-1145$
[15] King J.N., Yeh F.C., Heaman J.Ch., Dancik B.P., Selection of wood density and diameter in controlled crosses of coastal Douglas-fir, Silvae Genet. 37 (1988) 152-157.

[16] Littel R.C., Milliken G.A., Stroup W.W., Wolfinger R.D., SAS ${ }^{\circledast}$ System for Mixed Models, Cary, NC, SAS Institute Inc., 633 p.

[17] Lynch M., Walsh B., Genetics and analysis of quantitative traits, Sinauer Associates. Inc., MA, 980 p.

[18] Megraw R.A., Wood quality factors in loblolly pine, TAPPI Press, Atlanta, GA, 89 p.

[19] Namkoong G., Introduction to quantitative genetics in forestry, USDA, Tech. Bull. No 1588, 1979, 342 p.

[20] Nicholls J.W.P., Dadswell H.E., Perry D.H., Assessment of wood qualities for tree breeding. II. In Pinus pinaster ait. from western Australia, Silvae Genet. 12 (1963) 105-110.

[21] Nicholls J.W., Preliminary observations on the change with age of the heritability of certain wood characteristics in Pinus radiata clones, Silvae Genet. 16 (1965) 18-20.

[22] Nicholls J.W., Assesment of wood quality for tree breeding. IV. Pinus pinaster grown in western Australia, Silvae Genet. 16 (1967) 21-28.

[23] Nicholls J.W., Within-tree variation in wood characteristics of Pinus radiata D. Don., Aust. For. Res. 16 (1986) 313-335.

[24] Nicholls J.W., Morris J.D., Pederick L.A., Heritability estimates of density characteristics in juvenile radiata wood, Silvae Genet. 29 (1980) $54-61$.

[25] Rawlings J.O., Pantula S.G., Dickey D.A., Applied regression analysis. A research tool, 2nd ed., Springer-Verlag, 657 p.

[26] Ridout B.G., Sorensson Ch.T., Lausberg M.J.F., Wood properties of twenty highly ranked radiata pine seed production parents selected for growth and form, Wood Fiber Sci. 32 (1998) 126-137.

[27] Rozenberg Ph., Cahalan Ch., Spruce and wood quality: genetic aspects (a review), Silvae Genet. 46 (1997) 270-279.

[28] Rozenberg Ph., Wang T.L., Aitken S.N., Bastien C., Cahalan C., Evaluating wood density components from pith to bark: a genetic comparison of indexing annual rings using cambial age versus physical year (Submitted).

[29] SAS Institute Inc., SAS/STAT ${ }^{\circledast}$ Software: Changes and Enhancements through Release 6.12, Cary, NC SAS Institute Inc., 1167 p.

[30] Searle S.R., Casella G., McCulloch C.E., Variance components, John Wiley \& Sons, New York, 1992, 501 p.

[31] van Buijtenen J.P., Einspahr D.W., Peckham J.R., Micropulping loblolly pine grafts selected for extreme wood specific gravity, Silvae Genet. 17 (1968) 15-19.

[32] Vargas-Hernandez J., Adams T., Krahmer R.L., Family variation in age trends of wood density traits in young coastal douglas-fir, Wood Fiber Sci. 26 (1994) 229-236.

[33] West P.W., Use of diameter increment and basal area increment in tree growth studies, Can. J. For. Res. 10 (1980) 71-77.

[34] White T.L., Hodge G.R., Predicting breeding values with applications in forest tree improvement, Kluwer Ac. Pub., Dordrecht, The Netherlands, $1989,367 \mathrm{p}$.

[35] Zobel B.J., van Buijtenen J.P., Wood Variation, it's causes and control, Springer-Verlag, 1989, $560 \mathrm{p}$.

[36] Zobel B.J., Jett J.B., Genetic of wood formation, Springer-Verlag, $1995,337 \mathrm{p}$.

[37] Zobel B.J., Sprague J.R., Juvenile wood in forest trees, Springer-Verlag, 1998, $300 \mathrm{p}$.

[38] Zobel B. J., Kellison R.C., The rate of growth syndrome, Silvae Genet. 27 (1978) 123-124. 
